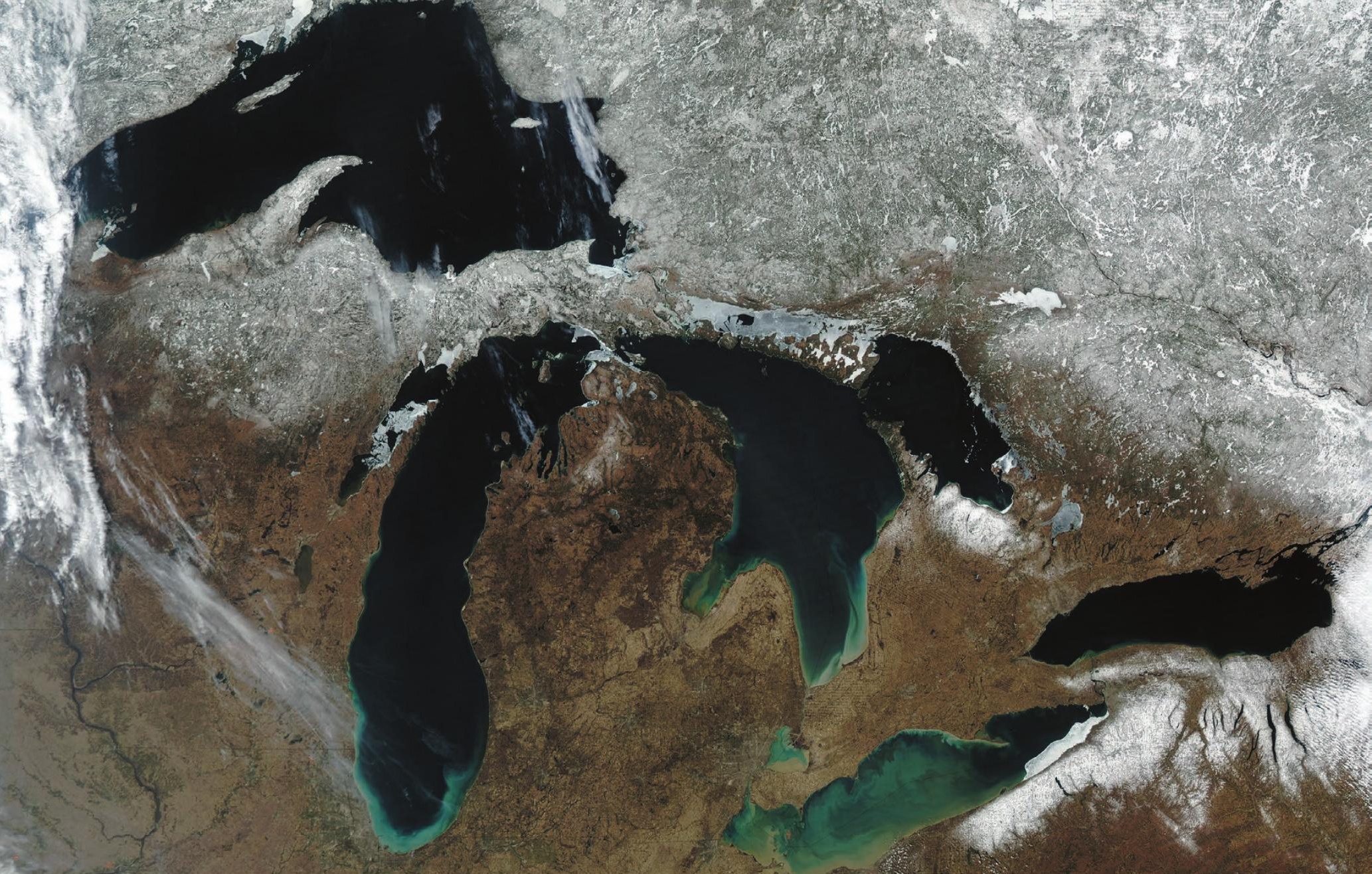

The Great Lakes on the US-Canadian border are under intense pressure.

\title{
Troubled waters on the Great Lakes
}

\section{Anna M. Michalak on the taming and invasion of Earth's largest fresh-water system.}

$\mathrm{T}$ The Great Lakes that straddle the border of Canada and the United States hold one-fifth of Earth's surface fresh water, and cover almost 250,000 square kilometres - an area larger than the United Kingdom. They are home to 3,500 species of plant and animal, including more than 170 species of fish. Some 30 million people live in their watershed. Their scale and natural beauty are inspiring, yet for hundreds of years they have also been viewed as a resource to be conquered. Now, a perfect storm of invasive species, pollution, climate change and other pressures is playing out in the region.

In his engaging The Death and Life of the Great Lakes, journalist Dan Egan traces the lakes' history, from the arrival of the first Europeans, such as French explorer Jean Nicolet - who in 1634 set out on Lake Michigan in a birch-bark canoe, looking for a passage to Asia - to the present. Egan's focus is on invasive species that tagged along as humans re-plumbed the Great Lakes to serve their needs. Starting with the parasitic sea lamprey (Petromyzon marinus), which had spread across the Great Lakes by the 1930s, these have dramatically altered the lake system and devastated native populations. Egan tells a tale of human ambition, ingenuity and hubris. He also speaks of redemption

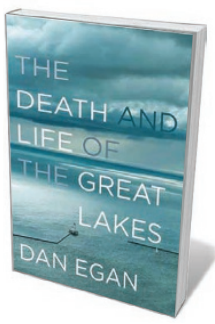

The Death and Life of the Great Lakes DAN EGAN

W. W. Norton: 2017. and opportunity.

The Great Lakes had a central role in the industrialization of the continent, and have thus seen massive engineering projects with two primary goals: to open up the North American interior to shipping, and to dispose of its sewage. These, Egan shrewdly dubs the front and back doors.

The completion of the first canal and locks goes back to 1781, culminating in 1959 with the opening of the Saint Lawrence Seaway. As seagoing vessels made their way deeper into the Great Lakes, they brought with them freshwater species from around the world, especially in ballast waters used to stabilize ships. Along with the lampreys, the protagonists of Egan's story are alewives (a type of herring, Alosa pseudoharengus) and zebra and quagga mussels (Dreissena polymorpha and Dreissena bugensis), which have successively upended the food web and overtaken the ecosystem.

The management responses to these invasions parallel the broader history of environmental-restoration efforts. A selective poison was developed to control lampreys in the 1950s, after fisheries collapsed in Lake Michigan, Lake Huron and Lake Superior. Non-native coho and Chinook salmon (Oncorhynchus kisutch and Oncorhynchus tshawytscha, respectively) were introduced to tackle alewives, starting in the 1960s. The dual mussel infestation that began in the late 1980s continues but, in a fascinating twist, native whitefish (Coregonus clupeaformis) seem to be evolving to feed on the mussels and on another 
non-native fish, the mussel-eating round goby (Neogobius melanostomus). Biologists are now exploring other ways to take advantage of native predators to tackle invasives. This shift towards leveraging the strength and complexity of natural systems is a recurring theme in environmental restoration.

The construction of the "back door" that links the Great Lakes to the Mississippi watershed - which drains $40 \%$ of the continental United States - was completed in 1848. This safeguarded the water supply for Chicago, Illinois, by sending sewage down the Mississippi River rather than into Lake Michigan. With it, the Great Lakes have become vulnerable to yet more invasive species, most notably the Asian carp that have overrun the Mississippi watershed.

We are still far from a solution, as Egan shows. Record-shattering extremes have abounded over the past decade across the Great Lakes, ranging from record low water levels immediately followed by record high ice cover and rises in lake levels, to massive 'dead zones' of hypoxia - low oxygen and harmful algal blooms. One bloom shut down the water supply in Toledo, Ohio, for two days in 2014.

Egan weaves solid quantitative scientific information into a narrative rich with tales of individuals who have spearheaded engineering projects, witnessed their consequences or studied their implications. This leaves the reader with a trove of knowledge, told like a great story rather than an academic lecture. I did wish for a few maps, pictures or diagrams to illustrate key ideas and to introduce the invasive protagonists. A deeper exploration of parallels with the expansion of non-native species in other parts of the world would also have been welcome, and links to water quality, fluctuating lake levels and climate change felt a bit tangential in places. Overall, however, the book is an impeccably researched portrayal of a fascinating story.

The path ahead is perhaps best illustrated by two quotes that Egan cites. In 1995, Ismail Serageldin, then World Bank vicepresident, opined that "the wars of this century have been fought over oil, and the wars of the next century will be on water". The US naturalist Aldo Leopold wrote in the 1940 s that "a thing is right when it tends to preserve the integrity, stability and beauty of the biotic community". This book is a reminder that human communities are part of the broader biotic community; it enjoins us to choose Leopold's vision, for the Great Lakes and beyond.

Anna M. Michalak is a faculty member in the Department of Global Ecology at the Carnegie Institution for Science in Stanford, California.

e-mail:michalak@stanford.edu

\section{Books in brief}

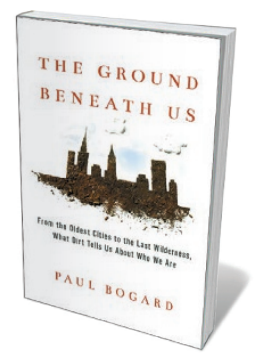

\section{The Ground Beneath Us}

Paul Bogard LITTLE, BRown (2017)

Science writer Paul Bogard chronicled the invasion of nocturnal darkness by light pollution in The End of Night (Little, Brown, 2013; see T. Radford Nature 499, 26-27; 2013). Here he delves into another overlooked resource - soil. This "wonderland" may be packed with one-third of all organisms, but we treat it like dirt: much of Manhattan is entombed under 125 million tonnes of materials. Bogard reminds us of the riches underfoot, from New York's Central Park soil biome, which teems with thousands of freshly discovered species, to terrestrial pitstops that keep migrating birds on the wing.

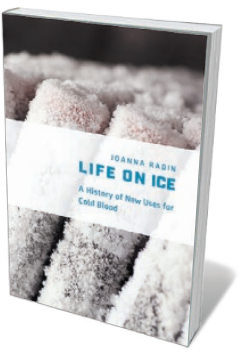

Life on Ice: A History of New Uses for Cold Blood

Joanna Radin UNIVERSITY OF CHICAGO PRESS (2017)

"These frozen populations, these time-travelling resources" - so medical historian Joanna Radin describes the estimated 600 million human tissue specimens biobanked for US medical research. Her sharply original history focuses on serum collected from indigenous communities and frozen during the cold war. Some samples have had a starry afterlife: one from the Belgian Congo, taken in 1959, later became the oldest trace of HIV/AIDS on record. Radin sweeps from the emergence of cryonics to the rise of genomics - and from burning ethical debates over indigenous rights to ancestral remains.

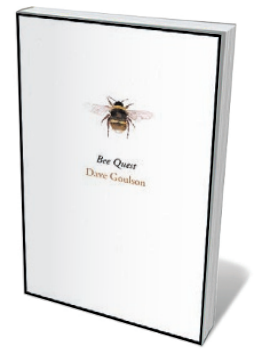

Bee Quest

Dave Goulson JONATHAN CAPE (2017)

Entomologist Dave Goulson journeyed as far as Patagonia to track down populations of the world's rarest bumblebees. The result is this fun serial travelogue and ode to diverse countryside. But Goulson is no misty-eyed nostalgic; he notes that subsidizing traditional farming practices could create "a Disneyesque parody of rural life". He ends on steps to bring insects back to cities, and the conviction that nature left alone recovers. In a world skewed towards saving photogenic mammals, Goulson extols the intrinsic importance of insects, rather than their economic value.

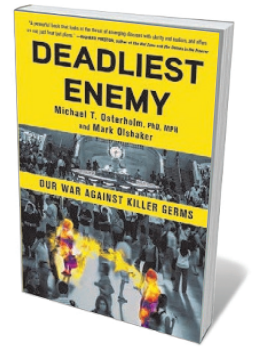

Deadliest Enemy: Our War Against Killer Germs

Michael T. Osterholm and Mark Olshaker LITTLE, BROWN (2017)

The real war on terror is the fight against pandemics — foes that can devastate entire regions at speed. Here, epidemiologist Michael Osterholm, with Mark Olshaker, describes science at that fraught frontline. A veteran of campaigns against SARS and Ebola, Osterholm draws on medical history and bruising personal experience to examine challenges ranging from political complacency to the microbial free-for-all of globalization. A 'tabletop exercise' imagining the impact of a virulent influenza epidemic today, and a clear plan for a global crisis response, give added weight to this call to arms.

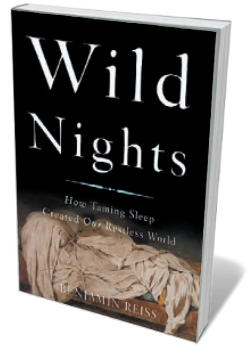

Wild Nights: How Taming Sleep Created Our Restless World Benjamin Reiss BASIC (2017)

Sleep is a culturally fluid phenomenon, reveals Benjamin Reiss in this marvellous scientific and literary study. He deftly interweaves multiple threads, from the industrial manipulation of time to the near-hibernation of snowbound Russian peasants in 1900, Henry David Thoreau's clock-free sojourn at Walden Pond, and the 50-cupa-day coffee habit of French novelist Honoré de Balzac. Sleep fascinates, Reiss reminds, because it is so many things: common denominator, "hidden dimension", field of dreams. Barbara Kiser 